\title{
Effect of Family Income, Education, Occupation, and Birth Weight on Child Growth at Aisyiyah III Kindergarten, in Kadipiro, Indonesia
}

\author{
Rusiana Sri Haryanti'), Bhisma Murti²), Eti Poncorini²) \\ 1) School of Health and Sciences, STIKes PKU Muhammadiyah, Surakarta, Indonesia \\ 2)Faculty of Medicine, Sebelas Maret University, Surakarta
}

\begin{abstract}
Background: Children under five years old are the future generation. Stages of child development during the golden period require stimulation to increase the potential of healthy children. As such the growth and development of children under five need serious attention. This study aimed to analyze the effect of family income, education, maternal occupation, and birth weight, on the development of children under five.

Subjects and Method: The study was observational analytic using cross sectional design. The study was conducted in Kindergarten of Aisyiyah III Kadipiro in May-June 2016. A total sample of 50 subjects was selected for this study. The independent variables were family income, education, maternal occupation, and birth weight. The dependent variable was child development. The data were analyzed using a multivariate linear regression model.

Results: Family income had a negative relationship with child development, but was not statistically significant $(\mathrm{OR}=0: 13 ; 95 \% \mathrm{CI}<0.01$ to $5.02 ; \mathrm{p}=0.274)$. Maternal education $(\mathrm{OR}=$ 22.22; $95 \% \mathrm{CI}=1.35$ to $365.07 ; \mathrm{p}=0.030)$, occupation ( $\mathrm{OR}=96.18 ; 95 \% \mathrm{CI}=1.69$ to 5644.84 ; $\mathrm{p}=0.027)$, and birth weight $(\mathrm{OR}=32.21 ; 95 \% \mathrm{CI}=1.76$ to $588.84 ; \mathrm{p}=0.019)$, had positive and statistically significant relationship with child development.

Conclusion: Maternal education, maternal occupation, and birth weight have positive effect on child development.
\end{abstract}

Keywords: family income, education, occupation, birth weight

Correspondence:

Rusiana Sri Haryanti. School of Health, STIKes PKU Muhammadiyah, Surakarta, Indonesia. Email: rusianamolyn@gmail.com.

\section{BACKGROUND}

The quality of child development needs serious attention. Children under the age of five need to have good nutrition, as well as sufficient and affordable stimulation by health services including early detection and intervention on child growth impairment (Depkes, 2006).

The first five years of life is a very sensitive period towards the surrounding. This period lasts very short and can not be repeated. That is why this period is called "Golden Period", "Window of Opportunity", and "Critical Period". For those reasons, children under the age of five need development stimulation (Depkes, 2006).

There are many factors that can affect child growth, such as genetic factor, surrounding area, culture, economic condition, education, social, climate or weather, nutritions, and many more. Genetic factor plays an important role in child growth and development. Gender, race, ethnic group, and cell growth speed are all included as genetic factors (Hidayat, 2008). Besides that, it is also affected by surrounding factors, namely biological, physical, psychological, and social surrounding (Mansur, 2009). KPSP 
is used to measure the growth of children under five years of age, it is recommended by the Ministry of Health. KPSP or PreScreening Growth Questionnaire is one of the screening tools that must be used in primary level health services. KPSP is very easy to be used by health officers, even by kindergarten teachers, pre-school teachers, or parents to detect child growth impairment as early as 3 months old, so that an early intervention can be taken.

This study was aiming at : 1) analizing the effect of family income on pre-school child growth in TK Aisyiyah III Kadipiro, 2) analizing the effect of education on preschool child growth in TK Aisyiyah III Kadipiro, 3) analizing the effect of maternal occupation on pre-school child growth in TK Aisyiyah III Kadipiro, 4) analizing the effect of birth weight on pre-scool child growth in TK Aisyiyah III Kadipiro, and, 5) analizing the effect of family income, education, maternal occupation, and birth weight on pre-school child growth in TK Aisyiyah III Kadipiro.

Family income is the amount of money a family get from stable income and side job of the breadwinner, mother, and other family members in a month divided by the number of family members as stated in rupiah per capita per month (Ernawati, 2006). According to Law No. 20 Year 2003 of the Republic of Indonesia, the level of formal education is structured and it consists of: 1. Primary education, 2. Secondary education, and 3. Higher education. Informal education consists of the education of one's family and the education from the community that take place naturally, while non-formal education is the education that take place outside formal education, and it can be carried out through different levels. It consists of courses, trainings, study groups, and community learning centers.
Women's empowerment education and others (Ahmadi, 2014).

Occupation or profession is an activity that one does to earn a living or to get remuneration to develop his potentials or skills in order to fulfil his needs. But there are occupations which are done for mutual interest and do not earn money, such as being a homemaker who takes care of the house and provides what the family needs (Widiantoro et al., 2007). A normal newborn baby is a baby that is born from aterm pregnancy (37-42 weeks) with the birth weight of 2500-4000 grams. Birth weight is the weight of the baby that is measured 1 hour after he was born.

Development is a result of the interaction of the central nervous system and the organs that it influences, for example the development of neuromuscular system, speech ability, emotion, and socialization. All of these functions are very important in the development of human as a whole (Depkes, 2006).

Growth is the increase structure in a regular pattern as a result of maturation process. It involves the body cell differentiation, body tissue, organs and organ systems which of a complex skill in body function and develop so that each can fulfil the functions, including emotional and intellectual, and behavioural development as a result of the interaction with the surrounding (Ngastiyah, 2005).

One of the ways to measure child growth is by using Pre-Screening Development Questionnaire or KPSP. It is a list of simple questions which is addressed to parents and it is used as a tool to do earlier growth screening of children as young as 3 months old until 6 years old. It has 10 questions to be asked to parents or babysitters in each of the age category. 
SUBJECTS AND METHOD

The study was observational analytic using cross sectional design. The study was conducted in Kindergarten of Aisyiyah III Kadipiro in May-June 2016. A total sample of 50 subjects of pre-school students was selected for this study. Data collection instrument were questionnaire paper and KIA book. The data analysis was univariate, bivariate using chi square and multivariate with double linear regression model.

\begin{tabular}{l}
\hline RESULTS \\
\hline A. Univariate Analysis \\
1. Subject characteristics \\
Table 1 shows that as many as 30 (60\%) \\
from 50 subjects have high income, as \\
many as $43(86 \%)$ have high education, as \\
many as 36 (72\%) maternal occupation, \\
and as many as 42 (84\%) have children \\
with normal birth weight.
\end{tabular}

Table 1. Characteristic of subjects in Aisyiyah III Kindergarten Kadipiro

\begin{tabular}{lcc}
\hline \multicolumn{1}{c}{ Variables } & n & \% \\
\hline Family Income & 30 & 60 \\
High & 20 & 40 \\
Low & & \\
Maternal Education & 43 & 86 \\
High & 7 & 14 \\
Low & & \\
Maternal Occupation & 36 & 72 \\
Working & 14 & 28 \\
Not working & & \\
Birth weight & 42 & 84 \\
Normal & 8 & 16 \\
BBLR & & \\
Child development & & 84 \\
Appropriate & 42 & 16 \\
Inappropriate & 8 & \\
\hline
\end{tabular}

\section{B. Bivariate Analysis}

1. The relationship of family income with pre-school child development

The study shows that family with high income has possibility of having children with appropriate growth suitable with the age compared to family that has low income. Statistical Analysis shows that there is a positive relationship between family income and pre-school child development as much as $\mathrm{p}=0.027$.

2. The relationship of maternal education with pre-school child development

Study shows that mothers with high education have the possibility of having children with the appropriate development suitable with the age compared to mothers with low education. Statistical analysis shows that there is a positive relationship between maternal education andpre-school child development, as much as $\mathrm{p}=0.001$.

\section{The relationship of maternal occu- pation with pre-school child deve- lopment}

The study shows that mothers who are working are most likely to have children with appropriate development suitable with the age compared to mothers who are not working. Statistical ananlysis shows that there is a positive relationship between maternal occupation with pre-school child development, as much as $\mathrm{p}=0.001$.

\section{The relationship of maternal edu- cation with pre-school child deve- lopment}

The result shows that normal birth weight has higher possibilities to make child development suitable with the age compared to abnormal birth weight. Statistical analysis shows that there is a positive relationship between birth weight with pre-school child development $(\mathrm{p}=0.004)$.

Based on table 2, the result of multivariate analysis shows that there is a significant relationship among education, maternal occupation, and birth weight with pre-school child development. 
Table 2. Logistic regression analysis of the effect of family income, education, maternal occupation, and birth weight

\begin{tabular}{lcccc}
\hline \multicolumn{1}{c}{ Variable } & \multirow{2}{*}{ OR } & \multicolumn{2}{c}{ CI 95\% } & \multirow{2}{*}{ p } \\
\cline { 3 - 4 } & & Lower limit & Upper limit & \\
\hline Family income & 0.13 & 0.003 & 5.02 & 0.274 \\
Normal birth weight $(\geq 2,500$ g) & 32.21 & 1.76 & 588.84 & 0.019 \\
Maternal education ( $\geq$ Senior High & 22.22 & 1.35 & 365.07 & 0.030 \\
School) & & & & \\
Maternal occupation (working) & 96.18 & 1.69 & 5466.84 & 0.027 \\
N observation & 50 & & & \\
-2 log likelihood & 22.05 & & & \\
Nagelkerke R ${ }^{2}$ & $60.7 \%$ & & & \\
\hline
\end{tabular}

Mothers with higher education (SHS and university) have the chance of $\mathbf{2 2 . 2 2}$ higher to have children with appropriate development suitable with the age compared to mothers with lower education (JHS and elementary school).

The analysis shows that there is a relationship between maternal occupation with child development and it is statistically significant $(\mathrm{OR}=96.18 ; 95 \% \mathrm{CI}=1.69$ to 5644.84; $\mathrm{p}=0.027)$. The analytical result it is statistically significant $(\mathrm{OR}=96.18 ; 95 \%$ $\mathrm{CI}=1.69$ to $5644.84 ; \mathrm{p}=0.027$ ).

There is a negative relationship between family income with child development and it is not statistically significant ( $\mathrm{OR}=0.13 ; 95 \% \mathrm{CI}<0.01$ to $5.02 ; \mathrm{p}=0.274)$. shows that mothers who are working have the chance of 96.18 higher of having children with appropriate development suitable to the age compared to mothers who are not working.

The result from Wald test shows that there is a relationship between family income with child development and it is not statistically significant $(\mathrm{OR}=0.13 ; 95 \% \mathrm{CI}$ $<0.01$ to 5.02; $p=0.274)$. Mothers with low family income have the chance of 0.13 higher of having children with appropriate development according to the age compared to mothers with higher family income.

The result from Wald test shows that there is a birth weight relationship with child development and it is statistically significant $(\mathrm{OR}=32.21 ; 95 \% \quad \mathrm{CI}=1.76$ to 588.84; $\mathrm{p}=0.019)$. Children with normal birth weight have the possibility of 32.21 higher to have children with development appropriate to the age compared to children with abnormal birth weight.

The Negelkerke $\mathrm{R}^{2}$ as much as $60.7 \%$ means that the four independent variables (maternal education, maternal occupation, birth weight, and family income) can explain child development suitable to the age as much as $60.7 \%$ and the rest, $39.30 \%$, is explained by other factors.

\section{DISCUSSION \\ 1. The effect of family income on pre- school child development}

The result of the study shows that there is a negative effect between family income and child development and it is not statistically significant. It means that if the family income is better, it does not always increase child development. This is caused by the daily buying, if it is not suitable with the nutritions needed for children, then it will cause inappropriate child development based on the age.

This finding is supported by a study from Raffalovich, Monnat, and Tsao (2009), that family income is one of the factors that support the growth and development of children. Low family income is always relat- 
ed to lack of food, bad health environment that will hinder the growth and development of children. Besides that, low income results in low purchasing power, including purchasing power for food, either in quality or in quantity that have impact on family nutritional needs. The effect of education on pre-school child development.

The result of the study shows that there is a relationship between maternal education and child development and it is statistically significant $p=0.030$, whereas the higher maternal education, the more information she has on how to educate children, thus child development is suitable with the age. This statement is in accordance with Ali (2009), the higher one's education is, the more skills and abilities that person has. These skills and abilities may not be owned by everyone.

A mother's role plays an important part in the growth and development of a child. A mother is fully responsible for taking care of her children and stimulizing their growth. Therefore, maternal education is very related with child development (Lestari, 2012). Maternal education is closely related to her knowledge. A mother who has higher education will make more efforts to find information to increase her knowledge and skills that she has, especially on how to take care of her children. Parents with higher education comprehend knowledge/ information better.

2. The effect of maternal occupation on pre-school child development

The result of tthe study shows that mothers who are working are able to fulfil needs for living, increase income, and gain a decent living and and the family prosperity will also increase. When family prosperity is achieved, then her life will be peaceful and comfortable, and this will give good impact to appropriate child development suitable with the age. The results of the study is in line with the study that was conducted by Suhardjo (2010), that mothers who are working will complete information, especially on how to stimulize the children development.

\section{The effect of birth weight on pre- school child development}

The result of the study shows that if a baby is born with normal birth weight it will increase child development. This is in line with the study that was conducted by Muscari (2005) that says there are differentiation process that take place in the cell, tissue, organs, and organ system that each of which is developed to fulfill its needs.

Based on this study, it can be concluded that there is a possitive relationship between maternal education and child development, and it is statistically significant $(\mathrm{OR}=22.22 ; 95 \% \mathrm{CI}=1.35$ to $365.07 ; \mathrm{p}=$ 0.030 ).

There is a possitive relationship between maternal occupation with child development and it is statistically significant $(\mathrm{OR}=96.18 ; 95 \% \mathrm{CI}=1.69$ to $5644.84 ; \mathrm{p}=$ 0.027).

There is a negative relationship between family income with child development and it is not statistically significant $(\mathrm{OR}=0.13 ; 95 \% \mathrm{CI}=0.003$ to $5.02 ; \mathrm{p}=$ $0.274)$.

There is a possitive relationship between birth weight with child development and it is statistically significant ( $\mathrm{OR}=32.21$; $95 \% \mathrm{CI}=1.76$ to $588.84 ; \mathrm{p}=0.019$ ).

\section{REFERENCE}

Adriana D (2011). Tumbuh kembang dan terapi bermain pada anak. Jakarta: Salemba Medika.

Ahmadi R (2014). Pengantar pendidikan. Yogyakarta: Ar-ruzz Media.

Ali M (2009). Pendidikan untuk Pembangunan Nasional: menuju bangsa Indo- 
nesia yang mandiri dan berdaya saing tinggi. Jakarta: Grasindo.

Ariani, Yosoprawoto M (2012). Usia anak dan pendidikan ibu sebagai faktor risiko gangguan perkembangan anak. Jurnal Kedoteran Brawijaya 27(2): 89-90.

Ariwibowo AA (2012). Jumlah balita Indonesia mencapai 31.8 juta jiwa. http:// www.antaranews.com/berita/332282 /jumlah-balita-indonesia-mencapai318-juta-jiwa diakses pada 20 November 2015 .

Baradja A (2005). Psikologi perkembangan, tahapan-tahapan dan aspek-aspeknya dari o tahun sampai akhil baliq. Jakarta : Studia press.

BKKBN (2014). Kependudukan Indonesia Alami Triple Burden. http://www.bkkbn.go.id/ViewBerita.aspx?BeritaID=1030. Diakses 21 November 2015.

Depkes RI (2006). Pedoman pelaksanaan stimulasi, deteksi dan intervensi dini tumbuh kembang anak di tingkat pelayanan kesehatan dasar.

(2010). Pedoman pelaksanaan stimulasi, deteksi dan intervensi dini tumbuh kembang anak di tingkat pelayanan kesehatan dasar.

(2012). Profil kesehatan Indonesia. Kementrian Kesehatan Republik Indonesia: Jakarta.

Ernawati A (2006). Hubungan faktor sosial ekonomi, higiene sanitasi lingkungan, tingkat konsumsi dan infeksi dengan status gizi anak usia 2-5 tahun di kabupaten Semarang Tahun 2003. Tesis. Program pascasarjana, Universitas Diponegoro: Semarang.

Hastuti (2010). Nilai anak, stimulasi psikososial dan perkembangan kognitif anak usia 2-3 tahun pada keluarga rawan pangan di Kabupaten Banjarnegara Jawa Tengah. Institusi Per- tanian Bogor. Jurnal Ilmu Keluarga \& Konseling 3(1): 27-34.

Hidayat AA (2005). Pengantar ilmu keperawatan anak. Jakarta: Salemba Medika

Kosim (2012). Buku ajar neonatologi. IDAI. Jakarta: EGC

Mansur H (2009). Psikologi Ibu dan Anak untuk Kebidanan. Jakarta: Salemba Medika

Mc. Gregor SG, Cheung YB, Cueto S, Glewwe P, Richter L, Strupp B (2007). Developmental potential in the first 5 years for children in developing countries. Lancet 369 (9555): 60-70.

Murti B (2013). Desain dan ukuran sampel untuk penelitian kuantitatif dan kualitatif di bidang kesehatan. Yogyakarta: Gajah Mada University Press.

Palasari W, Purnomo DISH (2012). Keterampilan ibu dalam deteksi dini tumbuh kembang terhadap tumbuh kembang bayi. Jurnal STIKES 5(1).

Potter PA, Perry AG (2009). Fudamental keperawatan (Edisi7). Jakarta: Salemba Medika.

Raffalovich LE, Monnat SM, Tsao H (2009). Family Income at the bottom and at the top: income sources and family characteristics. Res Soc Stratif Mobil 27(4): 301-309.

Saifuddin A (2010). Tes prestasi, fungsi dan pengembangan pengukuran prestasi belajar. Yogyakarta: Pustaka Pelajar.

Suharjo (2010). Pemberian makanan pada bayi dan anak. Yogyakarta: Kanisius.

Sulisnadewi NLK (2011). Efektivitas pendidikan kesehatan keluarga terhadap peningkatan kemampuan ibu dalam merawat anak diare di RSUP Sanglah dan RSUD Wangaya Denpasar. Tesis.

Supariasa (2002). Penilaian Status Gizi. Jakarta: EGC.

Widiantoro (2007). Pengetahuan sosial. Bogor: Quadra. 
Journal of Maternal and Child Health (2016), 1 (1): 1-6

https://doi.org/10.26911/thejmch.2016.01.01.01 